Eduardo da Motta e Albuquerque

(Cedeplar-UFMG)

\title{
VISIBLE SEEDS OF SOCIALISM AND METAMORPHOSES OF CAPITALISM:
}

\author{
Socialism after Rosdolsky
}

\begin{abstract}
Roman Rosdolsky suggests a method to deal with the transition towards socialism that integrates three issues: 1) the identification of dynamic features of capitalism; 2) the systematization of metamorphoses of capitalism; 3) the evaluation of how these metamorphoses reshape the elaboration of alternatives to capitalism. This evaluation is a precondition for the visualization, within the complex dynamics of capitalism, of seeds of a new society - institutions born out of political struggles and of emancipatory features of key social processes. These institutions reshape the nature of the metamorphoses of capitalism - and the possibility of establishing socialism and democracy.
\end{abstract}

KEY WORDS: metamorphoses of capitalism; technology and finance; socialism and democracy.

\section{RESUMO}

Rosdolsky sugere um método que trata da transição ao socialismo através da articulação entre três questões: 1) captar os elementos dinâmicos e contraditórios centrais na dinâmica capitalista; 2) sistematizar as metamorfoses mais importantes do sistema capitalista no longo prazo; 3) discutir as implicações dessas metamorfoses para a elaboração de alternativas ao capitalismo. A avaliação das metamorfoses do capitalismo é um prérequisito para a visualização de germes da nova sociedade na atualidade - arranjos institucionais que cristalizam resultados de lutas e de tendências emancipatórias presentes em processos sociais básicos. Arranjos institucionais que impactam as metamorfoses do capitalismo - e a possibilidade da transição para o socialismo.

PALAVRAS-CHAVE: metamorfoses do capitalismo; tecnologia e finanças; socialismo e democracia.

JEL: P10, P20, P40

Belo Horizonte, 15 June 2012

ÁREA 1: Escolas do Pensamento Econômico, Metodologia e Economia Política 


\section{INTRODUCTION}

Roman Rosdolsky offers new terms for the contemporary debates on socialism different from those that have preponderated in recent elaborations on the plan and the market, strongly influenced by Hayek (Roemer, 1996, for example). ${ }^{1}$ Burczak's (2006) book Socialism after Hayek crystallizes this influence more completely.

Among Rosdolsky's contributions, one can highlight the discussion on the "historical limits of the law of value: Marx on the subject of socialist society" - chapter 28 of The Making of Marx's Capital. Rosdolsky organizes this chapter by interweaving the discussion on "human individuality under capitalism", on the role of the machinery in the transition to socialism, and on the extinction of the law of value in socialism, This intertwinement represents a return to a broader treatment of Marx's work, not only in the reading of his work, particularly Capital, but also to the necessary articulation between the investigation of the capitalist dynamic and the discussion of socialist alternatives. As Rosdolsky (1968, p. 345) claims in the opening of chapter 28, in the original plan of Capital, Marx intended to discuss the transition to socialism in his last book (this topic is in the plan presented in Grundrisse, p. 345).

Rosdolsky's specific contribution to the theme of the transition to socialism, found in chapter 28 of his book, enriches the present debate by proposing a distinct starting point that has been little explored. What is Rosdolsky's Agenda? Starting from a question of method incorporated in his work, the articulation between two elements is central to the definition of Rosdolsky's Agenda. On the one hand, it is worth investigating the metamorphoses of capitalism. The understanding of those metamorphoses leads to a clear position on the possibility of building socialism in our time, which is greater than in Marx's era. On the other hand, the development of capitalism contains elements, tendencies and aspects which prefigure a new society and one of the challenges includes visualizing the seeds of this new formation in history (Rosdolsky, 1968, p. 345).

Chapter 28 presents a method, which according to Rosdolsky's interpretation (1968, p. 361), is the association, by Marx, between the investigation of capitalism and the socialist perspective. Hence, the investigation of the metamorphoses of capitalism and the efforts to visualize the seeds of a new society in history (Rosdolsky, 1968, p. 345) define Rosdolsky's Agenda for the discussion of socialism.

The basic contours of a proposal to update the elaboration of alternatives to capitalism requires the investigation, in the long term dynamics of capitalist development, of tendencies and processes which can contain elements of progress that lead to a new society. The point of departure of this investigation is the interpretation, from Marx himself, of the existence of elements of a new mode of production in the reduction of the working day and in the free time potentially generated by the application of science to production (Marx, 1857-58) and in the development of the credit system (Marx, 1894).

In relation to the role of free time in the transition to socialism, the discussion on the machinery - the relationship between the increase in the productivity of labor and free time - can be found in thid volume of Capital, in the section entitled "The revenue and its

\footnotetext{
${ }^{1}$ The present debate is the fourth round of a long-lasting debate on market and planning in the transition towards socialism. The first round is the socialist calculation debate (Barone, Mises, Lange and Hayek), the second is the debate on market and plan in the Soviet industrialization (Preobrajesnky and Bukharin), the third is the 1980s debates on plan, market and democracy in the USSR's crisis (Nove, Mandel and Elson) and, finally, the fourth round is dominated by market socialism (Roemer, Wright, Burczak).
} 
sources" (1894, pp. 951-1026). In this section, there are excerpts quite similar to the reasoning found in Grundrisse. Marx, after a comment on "the realm of freedom", he stresses that "[t]he reduction of the working day is the basic prerequisite" (p. 959).

In relation to credit, it is worth noting the abundance of Marx's references to the transition to a new society in his chapter on "the role of credit in capitalist production" of the third volume of Capital. It is important to point out the references to the role of credit as a "form of transition towards a new mode of production" (1894, p. 572). This theme is resumed in chapter 36, with a discussion of the Saint-Simonian positions on credit: Marx mentions the role of the "powerful lever" that the credit system "will serve ... in the course of transition from the capitalist mode of production to the mode of production of associated labour" (1894, p. 743).

These two excerpts indicate elements of a method in Marx for dealing with the transition to socialism: present tendencies and potentials inside of capitalism are bases for a new mode of production.

\section{1- THREE INTERPRETATIONS ON MARX AND SOCIALISM}

The way Marx deals with the topic of socialism is the object of controversy among various approaches. It is possible to organize these different interpretations into at least three distinct positions.

The first position considers that Marx did not sufficiently develop the question of socialism, as summarized in Blackburn's (1991, p. 13) formulation, which claims that there is an "excessive restraint" with regard to the topic. Hayek (1935, p. 128) ${ }^{2}$ and Nove (1983) can be identified in this perspective. Prychitko (2002) presents this as the "orthodox" position. In general, this perspective makes little reference to Marx's texts. For example, in the collection Socialist Economics, organized by Nove and Nutti (1972, pp. 19-26), there are only three of Marx's texts (an excerpt from Critique of the Gotha Programme, one from the Manifesto and one from the Manuscripts of 1844).

The second position is defended by Lavoie (1985b, p. 30): socialism for Marx would be the negative of capitalism. In Prychitko's (2002) opinion, this establishes Marx as an organizational theorist.

The third position is presented by Rosdolsky (1968): an investigation on capitalism, including its evolutionary tendencies, serves to indicate elements present in society that would potentially have characteristics of the new society. In this sense, socialism would be the product of these processes and its development would be noticeable in modern day societies, or in the most advanced capitalist countries.

Rosdolsky (1968, p. 345) interprets Marx's conception in a way in which "the socialist society of the future could only be spoken of inasmuch as visible seeds of this new social form could be discovered in history and its developmental tendencies". 3

Rosdolsky's proposition is an elaboration on the "visible seeds" for a transition to socialism. This interpretation emphasizes that the basis for the new society originates in capitalist society, in both its contradictory development, which includes the organization and historical achievements of the working class, and in its internal dynamic. These

\footnotetext{
${ }^{2}$ According to Hayek, "Marx himself had only scorn and ridicule for any such attempt to construct a working plan for such a utopia" (1935, p. 128).

${ }^{3}$ This is the translation of the English edition of Rosdolsky's book.
} 
elements should be "visible" in history. This dynamic, in fact, is an important element for capitalism itself in the long run, as an additional source for its metamorphoses.

Visible seeds of socialism emphasize institutional arrangements that developed throughout the history of capitalism. Visible seeds are materialized in institutions and in institutional arrangements. As they are embodied in new institutions, they become part of the dynamics of a capitalist society. Like specific institutional arrangements, they have their own life and own dynamics. For this reason, they should not be confused with the State or with its structural transformations.

The emphasis on the distinct and specific nature of these visible seeds is supported by studies focusing on such institutional arrangements. For example, the neoSchumpeterian literature on innovation systems insists on the singularity of these specific institutional arrangements (Freeman, 1988; Nelson, 1993). With regard to the welfare system, Esping-Andersen (1995, p. 714) evaluates "the emergence of a historically novel and unique institutional construction", while Goodin (1988, p. 3) describes it as "a political artifact". 4

In general, the "visible seeds" are results of social struggles, of strongly emancipatory forces or of inherently communitarian elements embedded in these institutional arrangements. The emancipatory potential of science is fundamental for the characterization of the institutional arrangement of "innovation system" as a visible germ. The difficulty of completely subordinating science to capital is an example of this nature. The anti-capital origin and civilizing force of welfare systems, with its capacity for incorporating excluded groups, lead to the de-commodification of labor and generate ascending social mobility. This is what allows it to be characterized as a "visible seed". 5 The social nature of credit and the role of "the community as a whole" - "... which provides a real value corresponding to money" (Simmel, 1907, p. 177) - would constitute a basis for the characterization of the financial system as a visible seed - a complex and very mediated seed. Finally, the institutional arrangements of democracy have a never-ending confrontation with the logic of capital and constitute the foundation for overcoming capitalism. The origins of "visible seeds", therefore, are diverse.

The visible seeds of socialism are generated according to processes that re-appear in a systematic manner throughout history. They crystallize themselves in new institutions and end up becoming the non-intentional results of these processes. They may have been limited, valid in short periods of time or territorially located, but they are concrete possibilities, or successful experiments. And, it is for this reason that they are contributions to the reflection on socialism.

The identification of "visible seeds" does not imply a predefined or an automatic trajectory that these seeds will take. Here, one of the meanings of the word seed (see Webster) is quite clear: "the source, origin or beginning of anything" contains as an alternative state its non-development. Nevertheless, as the "visible seeds" become the institutional condensation of the results of social struggles or of actions from emancipatory

\footnotetext{
${ }^{4}$ Rosdolsky was not able to take advantage of the academic studies on innovation systems (Freeman's work is from the mid 1980s) and on welfare systems (Esping-Andersen's work was published in 1990).

${ }^{5}$ Additionally, restricting the experience of the most advanced welfare system only to one country - small and socially homogenous - like Sweden, is an example of the enormous difficulties that global capital has in generalizing the potential contained in this institutional arrangement.
} 
forces, these results have their own dynamic - again, with a strong indetermination with regard to their development.

The institutions which embody the visible seeds represent a possibility of breaking with the logic of capital. While capital already has its own defined dynamic, governed by the incessant search for profit and super-profit, visible seeds can break this dynamic by introducing a prior concern: questions on the consequences of decisions, actions and priorities emerge. These questions, which remain outside of the logic of capital, also create a new question related to who decides: the theme of democracy is implicit in this distinct logic. In this sense, there is a clash between the logic of capital and the potential dynamic of visible seeds.

Rosdolsky also suggests that the struggle for socialism is not indifferent to the present advances in capitalist society. In an excerpt from his classic book, after widely discussing the role of the machinery as fundamental for the transition to socialism in Marx, he comments on how the technological development in the period after World War II - a "new industrial revolution" - multiplied that potential (1968, p. 356). Hence, Rosdolsky calls attention to the need for identifying the differences between Marx's era (a prehistorical age of the technological application of science) and the subsequent ones.

\section{2- METAMORPHOSES OF CAPITALISM AND THE PROGRAMMATIC RECOMPOSITION OF THE SOCIALIST PERSPECTIVE}

The capitalist system has high flexibility in the long run, with its history made up of various important metamorphoses. These metamorphoses can be described either by the theory of "long waves of capitalist development" (Freeman \& Louçã, 2001) or by the theory of "systemic cycles of accumulation" (Arrighi, 1994).

There are various sources for these metamorphoses. The first source includes metamorphoses determined by the articulation between the technological and financial dynamic inherent in the capitalist system, which impacts processes of "making and remaking of the world's working classes" (Silver, 2003, p. 171). The second source stems from the investigation of long term dynamics, which requires the incorporation of the State and of political elements such as wars (with all the economic and industrial mobilization it establishes), in the configuration of these metamorphoses. The third source, a decisive element in molding contemporary capitalism, is the interaction between these dynamics and social struggles (in a broad sense). The interaction is complex since it involves labor unrest, strikes, pressures, demands, struggles, and the interplay between those struggles and the capitalist system. Certainly, the technological elements of the capitalist dynamic determine a growing margin for maneuvering and shifting the system, and therefore making it capable of incorporating at least part of those demands.

The interaction between social struggles and the capitalist dynamic involves claims that are as elementary as the reduction of the working day, the prohibition of child labor, the increase of wages and improved working conditions, all of which Marx highlights in Capital as being important struggles of the first half of the $19^{\text {th }}$ century. As the most basic claims are met, new demands are presented given the very progress of social movements, as well as economic and technological progress. These changes, stirred up by the presence of social movements in the political life of central capitalist countries, determined (in a nonintentional manner) changes in capitalism, which led to the expansion of the market, a better income distribution and various new impacts on the dynamics of the system. In turn, 
these changes offered new sources for the growth of the market and new opportunities for economies of scale and scope.

The very dynamic of social movements also determines the emergence of institutional innovations, as exemplified by Bismarck's implementation of social protection measures related to diseases (1883), labor accidents (1884) and retirements (1889) at the same time in which anti-socialist legislation was established in Germany (Stachura, 2003, p. 229). These measures are important for the history of welfare systems of the $20^{\text {th }}$ century (Polanyi, 1944, p. 177; Esping-Andersen, 1990, p. 24). The historic result of these complex interactions is the process of creating welfare systems in advanced capitalist countries, which were then transformed into an important source of vitality for the capitalist system itself.

Lastly, the fourth source for the metamorphoses of central capitalism is the defensive reaction against the real or imaginary fears of important events in the international arena. Abendroth (1977, pp. 178-179), for example, highlights how the existence of the USSR contributed to important concessions for working classes in Western Europe, not only in terms of the quality of life, but also in terms of democratic rights. Amsden (1989) and Wade (1990) associate the attainment of agrarian reforms in South Korea and in Taiwan, through the influence of the United States, as reactions to the foundation of the People's Republic of China.

Thus, the metamorphoses of capitalism would be determined by these four different, though intertwined, sources of changes. The results of the four intertwined changes are the diverse phases of capitalism that have their own distinct structural characteristics. That is why the dynamic of the capitalist system, in the long run, systematically places new questions for the group of social movements and socialist political movements. Hence, the need for programmatic reconfigurations increases. Wood $(1995$, p. 4) emphasizes the need for and the complexity of this effort.

This increased need for programmatic reconfigurations can still be combined with elements related to the history and generational transition of social movements. The ability of incorporating social demands through the capitalist dynamic may possibly have astonished various generations of trade unionists and socialists. This perspective allows one to place, on a broader historical horizon, some crucial social and political processes such as the inclusion of social democracy in Germany's political establishment in the beginning of the $20^{\text {th }}$ century. Kautsky and Bernstein expressed their surprise, in programmatic terms, with regard to the capitalist system's capacity for metamorphosis, which had made the working day and quality of life for the working class improve dramatically in comparison to the conditions of mid- $19^{\text {th }}$ century. In addition, long processes of struggles, prior to the attainment of these demands, can lead to the breakdown of social energies geared towards continued mobilization. ${ }^{6}$ As old demands are incorporated, there should be better conditions for gaining strength to make new and updated demands.

There is a specific and complex timing for resuming mobilizations given these new conditions. In addition to the complex matters of timing and energy, eventually resuming

\footnotetext{
${ }^{6}$ Max Weber, in a letter written on November 18, 1918 and transcribed by Marianne Weber (1929, p. 746) and Trotsky (1937, p. 65 and p. 76), refers to this social phenomenon in the most extreme of circumstances: the breakdown of energies for working class's mobilizations after periods of intense political activity in revolutionary or national crises. This breakdown of energies has negative consequences for the political structuring of the following period.
} 
the processes of mobilization requires important programmatic reconfigurations. Perhaps the metamorphoses of capitalism generated more programmatic confusion on the left than adequate programmatic rearrangements. On the one hand, there is the phenomenon Rosa Luxemburg called "reformism". On the other hand, as a counterpoint of this phenomenon, sectors and policies associated with the negation of reformism had also difficulties in understanding and reorganizing the socialist program according to a changing capitalist reality.

How do the metamorphoses of capitalism determine the contours for programmatic reconfigurations?

This is precisely where Rosdolsky's position can be understood in all its depth. On the one hand, Rosdolsky's perspective emphasizes the need for identifying the technological and scientific level of each phase, particularly given the liberating potential found in the growing technological application of science. Technological advances create new possibilities for reducing the working day, improving working conditions and confronting the challenges placed by humanity, such as present environmental concerns, which are relevant matters that require both the increase and reorientation of technological progress. On the other hand, Rosdolsky's position suggests identifying the new society's "visible seeds", which are present within contemporary capitalist societies.

These formulations are compatible with the Critique of the Gotha Programme, where Marx reinforces how the new society must carry signs of the old society which it comes from. The more advanced the "old society", the better the starting point for building the new one. This perspective, in fact, is also discussed by Preobrajensky (1926) in his work on "primitive socialist accumulation". Strongly influenced by the Russian experience, Preobrajensky claimed that the society and economy which emerge with less destruction, in the beginning of the transition, will have a better starting point and a better subsequent process. Identifying the starting point of the new society should be carried out in a very precise manner since it permanently changes. The identification of the "visible seeds", therefore, contributes to organizing the programmatic reconfiguration.

In this programmatic reconfiguration, it is also useful to incorporate more localized experiments. To a certain degree, the Swedish experience is an experiment about the Welfare State. Keynes treated Sweden as an important experiment, lamenting the little visibility it received (Skidelsky, 1992, p. 488). Cohen and Rogers (1995) present various experiences that are more localized, among them the experience of participatory budgeting in Brazil.

The concern with permanent programmatic reconfiguration stems from the need for establishing a coherent and attractive socialist program with the ability to stimulate energies for mobilization, which at the very least, is an important civilizing factor of capitalism. The inexistence of this program would stimulate the development of the most antisocial elements of capital - with disastrous consequences for all of humanity.

Finally, in the metamorphoses in course in the capitalist system, there is a transition to a more international and global capitalism (Wood, 2003), which requires the greater internationalization of proposals for alternatives. 


\section{3- VISIBLE SEEDS OF SOCIALISM}

The present phase of capitalism in advanced countries contains diverse visible seeds of socialism: innovations systems, social-welfare systems, the dynamics set by the present financial organizations and democracy. The former holds precedence over the others.

Contemporary capitalism cannot be understood without incorporating these four institutional elements. All are products of historical developments or, in other words, the results of combinations among these four sources of the metamorphoses of capitalism. Different combinations and different institutional formats related to these four institutions generate different types of capitalism among the countries located at the center. It is worth mentioning that the literature on each of these four institutions is rich in elements that differentiate central capitalist countries in each of these topics: 1) for innovation systems, see Nelson (1993); 2) for social-welfare systems, see Esping-Andersen (1990); 3) for financial systems, see Zysman (1982); 4) for democracy, see Lijphardt (1999). The combination of the differences among these four elements provides us with a mosaic of varieties of capitalism. These, in turn, are important for locating what is singular in the "classic case" represented by the United States and also for the possibility of institutional changes in the processes of hegemonic transition.

Each of these institutional arrangements may be seen as bearers of a transformation potential sufficiently rich to justify its use in discussions on alternatives to capitalism now, in the beginning of the second decade of the $21^{\text {st }}$ century. There is a methodological assumption that the evaluation of each of these institutions, as singular human inventions, could potentially contribute to overcoming the limits of capitalism. Since these institutions have already been developed, dealing with them in the beginning of the $21^{\text {st }}$ century is not a purely fictional exercise. This can be an important advantage over the other present proposals in the actual debate on socialism.

\section{1- INNOVATION SYSTEMS}

The technological progress in advanced capitalist societies is propelled by complex institutional arrangements that involve firms, universities, research institutes, market and non-market institutions of selection, resources and public policies, in addition to private investments (Freeman, 1988; Nelson, 1993). This complex institutional arrangement expanded throughout the $19^{\text {th }}$ and $20^{\text {th }}$ centuries in order to make not only the development of science and basic research feasible, but also to apply and incorporate it in businesses. It is important to emphasize this aspect, in so far as the literature on alternatives to capitalism has not incorporated the results of neo-Schumpeterian investigations on the determinants and institutions that shape technological progress in capitalism (Roemer, 1996; Hodgson, 1999; Stiglitz, 1994; Burczak, 2006) - unfortunately they have evaluated technological progress only as a product of the market.

The inclusion of innovation systems in the elaboration of alternatives to capitalism is a corollary to the role of technology in this process of transformation. Innovation systems can be considered a "visible seed", given that they deal with an essential component in the transition to a socialist society: the innovation system is an arrangement that makes the "state of science and technology" evolve, which is a basic component for reducing the working day and for transforming the nature of labor.

Various essential questions for the development of humanity require enormous investments in the field of science and technology, beyond the significant matter of the nature of labor. The experience with innovation systems, given the complex interaction 
between their various constitutive institutions, is an important starting point for the articulation between priorities, in terms of science and technology and society's demands. To deal properly with science and technology, mechanisms of discussion and democratic deliberation need improvement and sophistication. Freeman's (1996) reflection on the increasingly important relationship between technology and the environment is an excellent introduction for this broad technological redirection. There are already tested mechanisms that allow for the development of projects that articulate scientific and technological dimensions in search of well-defined objectives: the mission-oriented projects (Freeman, 1996). These mechanisms are susceptible to some kind of reorganization in order to reorient technological progress, including the creation of new "focusing devices" for technological progress.

These new "focusing devices" of the direction of technological progress are feasible: there are innumerous experiments that have been done and are successful both locally and sectorally. The sensibility of scientific specializations in relation to social and technological priorities is perceptible in the case of the Nordic countries, where one can identify a strong scientific specialization in disciplines related to the health sector. This suggests a strong influence running from welfare systems to innovation systems.

The democratic reorientation of scientific and technological development is a crucial element here. This is not simple, since there are various existing logics in terms of scientific progress in general, and of the diverse applications and multiple interactions among the innovation system's different institutions.

In order to incorporate and adapt the innovation systems to projects that are alternatives to capitalism, an initial mechanism is related to various public and state mechanisms, which have been widely used and are treated as implicit mechanisms in the definition of these policies. They could be transformed by their subordination to conscious discussion and democratic deliberation of those mechanisms. Making these mechanisms more explicit also makes it easier to carry out broader discussions and to adjust innovation systems as effective tools for conscious public policies. Innovation systems are essential elements for the definition of the interaction between the plan and the market in the transition to socialism.

Finally, the incorporation of innovative systems is a consequence of the metamorphoses incurred by capitalism in the $19^{\text {th }}$ and $20^{\text {th }}$ centuries. In addition, innovations systems will have innumerous interactions with other "visible seeds".

\section{2- WELFARE SYSTEMS}

There are various structures of welfare systems in developed capitalist systems (Esping-Andersen, 1990). A classification of "pension regimes", for instance, includes on one extreme, the Swedish experience - a "universalistic state-dominated system" -, and on the other extreme, the United States - a "residualist system, in which the market tends to prevail" (p. 86).

The power of the dynamic of the "visible seeds" can be captured here, in so far as even the solution in the US case, "in which the market tends to prevail" - pensions in the private sector with Pension Funds acquiring corporate shares - created an enormous potential of transforming "the control of capital", as Fung et al (2001) suggest.

The developmental logic of welfare systems involves a particular interaction with social movements and with public policies for the dispute over the action of capital. 
Esping-Andersen's (1990) typology anticipates a pattern of dispute surrounding this visible seed, given that in the corporate type of systems (Germany), there is a tendency to crystallize the existing social structure, while in the more market-based systems (United States), the capital market seeks to make retirements one more sector of its activity. In this sense, the universalistic model, represented by the Swedish experience, is the format which, in fact, embodies this visible seed. Esping-Andersen's (1990) typology allows for a dialogue with Offe and Habermas's correct critique of the Welfare State, since both of these authors deal with the German version of these systems. At the same time, this typology shows that the Swedish version is the one which most advances in the direction of the de-commodification of labor and of the group of activities related to the welfare system.

One of the limitations of Esping-Andersen's typology is the fact the health system is not incorporated in the welfare system. Barr (1988), for example, deals with welfare systems in a more comprehensive manner. If Esping-Andersen had included the health system within the welfare system, he would have accentuated the specificity of the Swedish case even more, particularly for emphasizing the de-commodification of health as well (see Lassey et al., 1997). As capitalism can be identified with "the growing commodification of life" (Wood, 2003, p. 11), the de-commodification of labor and health through welfare systems shows the system's transformative potential for reversing the logic of capital.

The interaction between welfare systems and innovation systems also contributes to the construction of mechanisms that refocus the orientation of technological progress, which certainly strengthens the role of the health sector in economic development (a tendency, in fact, already in course in advanced capitalist societies). This strengthening of the health sector can have new implications in terms of the quality of life and the generation of creative human capacity. This, in turn, has an impact on the innovative dynamic of the new society.

Perhaps this is the "visible seed" that received more attention from Marx in one of his explicit reflections on the nature of the transition to socialism, even though this germ was not visible at the time. In the Critique of the Gotha Programme, when criticizing the establishment of an "integral retribution of labor", Marx shows the necessary deductions for the beginning of the transition to socialism - the "deductions" of the "total social product": 1) the replacement of the means of production; 2) expansion of production; 3) "reserve or insurance funds to provide against accidents, dislocations caused by natural calamities, etc"; 4) general administration costs; 5) "that which is intended for the common satisfaction of needs, such as schools, health services, etc"; 6) "funds for those unable to work, etc., in short, for what is included under so-called official poor relief today" (Marx, 1875, pp. 230-231). In this argument, there are three elements directly related to what has become the modern welfare system (points 3, 5 and 6). Marx clarifies that in this society in transition, while the expenses related to the administration would tend to fall, the part related to the collective necessities "from the outset, .... grows considerably in comparison with present-day society, and it grows in proportion as the new society develops" (p. 231).

The formation of welfare systems is a broad social process whose initial dynamic Marx had already alluded to in Capital and which is related to pressures coming from social movements seeking to gain certain social achievements such as the reduction in the working day. The growth of welfare-related expenses in capitalist societies during the $20^{\text {th }}$ century is an expression of the vigor of this "visible seed" and, in this case, of its potential to reconfigure capitalist societies. 


\section{3- DEVELOPMENT OF THE FINANCIAL SYSTEM}

Marx's references on the credit system as a "powerful lever" in the transition to a new society $(1894$, p. 743$)$ and to joint-stock companies as a "form of transition" to a new society (1894, p. 572) can be evaluated as reasonably fragmented and not developed (since they are in a written volume, but were not revised by Marx for publication). However, they are, to a certain extent, confirmed by various real or potential developments of modern capitalism.

From the dialogue with a post Keynesian formulation, an important paradox emerges, according to Minsky's (1982, p. 201) analysis: "Paradoxically, perhaps, private ownership capitalism does not work well for industries of extreme capital intensity". In this excerpt, Minsky discusses the role of public property.

Concrete developments (the growth of the credit system, development of joint-stock companies in the end of the $19^{\text {th }}$ century) were evaluated by Bernstein (1899) and by Weber (1918, p. 113) as a demonstration of the possibility of evolutionary developments (in opposition to revolutionary ones).

Drucker (1976) is insightful (and provocative) when identifying a concrete and existing tendency in the United States' economy, which would represent the apex of the development of the financial system, including the configuration of a type of capitalism where stock markets and anonymous societies have a central role: Pension Funds hold more than $70 \%$ of the United States' GNP in financial assets of which more than $70 \%$ are invested in corporate shares. This development opens room for explanations such as those of Blackburn (2002), who starts with the nature of pensions (in the Anglo-Saxon model), considered an element in the conventional financial market, and discusses two possible paths. One of these would lead to the "progressive socialization of the accumulation process" (p. 528). Blackburn (2002) articulates this perspective with the discussion of the "socialization of the market" presented by Diane Elson (1985).

The discussion on the meaning of Pension Funds and their transformative potential is relevant and there is extensive literature on the topic available. A basic typology of possibilities of actions from these Funds would have three categories: 1) passive Pension Funds, only one element of the modern financial system acting in accordance with the general rules of these markets (Mishkin and Eakins, 2009); 2) Pension Funds as an important element for transforming segments of the working class into active agents of capitalism, which Chesnais (2004, p.33) evaluates as the possibility of a "new class" and Drucker (1976, p. 149) highlights as the ambiguous character of the employees who have shares enough to influence corporations; 3) part of a strategy of economic and social reorientation, which includes what The Economist considers to be activist investors (social responsible investments), one of Blackburn's proposals (2002, p. 465), Fung's et al. (2001) discussion and Engelen's (2006) proposals. The dynamic of the visible seeds is related to this third category. This perspective is present in Maurício Borges Lemos' (1991) proposal - an alternative to the privatizations in Brazil based on a patrimonial transference from the Brazilian State to two new institutions that would have "elected boards by the vote of all union workers" (p. 81).

The dependence on Pension Funds, in relation to the performance of businesses (given the risk of having their shares devalued), has brought a new concern to workers: how to guarantee their future with their retirements? Is the financial market a guarantee of their 
future? In the 2007-2008 crisis, according to the Bank for International Settlements (BIS) report, pension funds lost $20 \%$ of the value of their assets (BIS, 2009, p. 48). The inevitable turbulences of the financial system and the repercussion on pension funds' assets have become new sources of concern with the economy for workers and pensioners. This can create new institutional experiments in relation to democracy (the extension of democracy in order to cover these new areas of action). Hebb (2001) presents challenges and opportunities of a "worker-owner agenda" for pension funds. One of the topics of this agenda always mentioned is the relative success of the use of stock holder positions in Pension Funds to press corporations during the antiapartheid struggle (Becker and MacVeigh, 2001, pp. 47-50).

Tracking another trajectory, Esping-Andersen (1985, p. 297) describes how the consolidation of the Swedish welfare system have triggered a specific dynamic of achievements, which gave origin to the Meidner Plan, approved by the Swedish central trade union (LO) in 1976. This plan had as its target the local corporations' superprofits, enabled by the workings of the Swedish welfare system. The Meidner Plan proposed the creation of institutional funds owned by the workers. These funds would be constituted by the annual transfer of $20 \%$ of the corporations' profits through corporate shares to those funds (p. 298). In the long run, the plan would mean a worker representation in control of these corporations. There was great resistance from the employers and, even when changed, the plan was not victorious. Nevertheless, this proposal is still present in the debate and was the object of commentaries from both Drucker (1976) and Blackburn (2002).

Another example is the initiatives of the United States government and the weight of public intervention related to the financial crisis of 2008. The result of these interventions paved the path for a discussion of a (temporary) nationalization of banks, which turns out to be an expression of a quite particular dynamic ("Nationalization gets a new, serious look", New York Times, 26/01/2009). In the New York Times pages, economists like Krugman ("Banking on the brink", 23/02/2009) and Stiglitz ("Obama's Ersatz Capitalism", 01/04/2009) argued in favor of the temporary nationalization of banks. This (necessary) increase in scope and dimension of the public sector potentially establishes new demands for democratic institutions: democratic control over public spending. This matter has already been dealt with explicitly by theorists in the literature, such as Pollin's (1995) proposal that searches for "methods of bringing dramatic increases in the democratic control over financial markets and the allocation of credit", through the articulation of achievements in associative democracy with the financial system (p. 47).

Through a different path, which starts with more general macroeconomic political questions, Keynesian proposals can lead to the establishment of welfare systems and contribute to structural reforms in the economy. Carvalho (2008, p. 209) emphasizes that Scandinavian social-democracy is Keynesian because it accepts Keynes' vision of the structural change of the productive sector. The commentary on the different paths involves a comparison with previous discussions on welfare systems. In one case, the concern with specific policies related to welfare leads to financial reforms (Meidner Plan); in another case, or the opposite path, the concerns with monetary and financial issues lead to proposals for establishing building blocks of a welfare system.

Carvalho's (2008) interpretation finds in Keynes - in general a reformer of capitalism - elements for an important structural reform that deal with two problematic issues for capitalism: the difficulty of reaching full employment and the inequalities in terms of income and wealth. Carvalho (2008) evaluates Keynes proposals as presented in 
How to pay for the war and the interventions in defense of the Beveridge Plan, and suggests that they could be considered socialist for two reasons: first, because they break the link between income and the market's performance; second, because the State would have the direct responsibility in the redistribution of income (Carvalho, 2008, pp. 208-209).

Lastly, in terms of alternatives at the theoretical level, it is interesting to note the proposals that utilize shares or the corporate nature of businesses for reforming capitalism or building market socialism: Roemer (1994) is an example, and Keynes, according to Carvalho (2008, p. 209), had also thought about reorganizing the productive system "[m]ostly based on the idea that joint-stock companies were already closer to a public company than to the individualistic capitalism of the nineteenth century".

Here there are multiple roads and experiments that can create a vast array of options for achieving, as Marx would say, the transformation of the credit system into a "powerful lever" for building a new society.

\section{4- THE PRECEDENCE OF DEMOCRACY}

Democracy is the most important institution in the transition to socialism. Socialism should be considered a consequence of the achievements in democracy and a result of democratic decisions. The tension between capitalism and democracy is discussed by Habermas (1981, volume II, p. 487).

In the history of the debates on economic planning, the theme of democracy enters the agenda only in a third round, particularly with Mandel's (1986) intervention. In the present round of debates, E.O. Wright's (2006) proposal emphasizes the quality of democratic institutions, with regard to their presence in society and the institutions they influence, in detriment of the structure of property per se. In dynamic terms, this approach is perfectly compatible with Mandel's (1985) suggestion.

The dialogue with those who study the democratic question is, therefore, decisive. This question is certainly that requires a very special interaction between Economics and Political Science. In fact, Economics has much to learn from this field. An introduction for this dialogue can be found in Cohen (1989, p. 26): “[a] commitment to socialism follows naturally from a commitment to democracy, where democracy is understood to be an association that realizes the ideal of free deliberation among equal citizens". Chantal Mouffe (1992, p. 1), in an important text for democratic theory, given that it discusses the implications of the end of burocratic regimes in Eastern Europe, reiterates that "the objectives of the Left should be the extension and deepening of the democratic revolution initiated two hundred years ago". The theme that emerges from this perspective is until what point can capitalism, as a system, survive with the effective extensions and entrenchments of democracy. This is why Cohen's (1989) approach is rich, for it not only points to the tension between democracy and capitalism, but also to the dynamic of democratic development that can put capitalism into question.

The dynamic element, in Cohen's argument, derives from a group of considerations that extend "from a commitment to democratic association to a commitment to a form of socialism" (p.26).

In order to ground his argument, Cohen establishes a selective revision of the literature on democracy. He presents what is central to understanding the dynamic, defining the process that would articulate democracy and socialism: the various sources of tension and contradiction between democracy and capitalism, which are also arguments in support of some type of "social property of capital" (p. 30). 
Cohen (1989, pp. 27-30) presents four arguments that arrive at socialist conclusions from democratic principles.

The first argument - the parallel case argument - bases its defense of the selfadministration of businesses according to a parallelism with the case of the democratic government of the State. According to Cohen (1989), Dahl is the theorist who presents this argument. The workers in a business, considered to be actors who cooperate in the business, have the capacity of evaluating the rules which define this cooperative activity and of subjecting themselves to such rules. It is for this reason that they have the right to determine these rules. As a result, "[s]ince the private ownership of capital conflicts with that right, it ought to be abolished, or at least carefully circumscribed" (Cohen, 1989, p. 27).

The second argument - the structural constraint argument - refers to the limits imposed on democracy by the private control of investments. This argument is presented by Przeworski (1985). The decisions made by capitalists can impede the implementation of decisions taken in a capitalist democracy. "[S]ince the private control of investment thus imposes important constraints on the collective choices of citizens, public control of investments is required as a remedy" (Cohen, 1989, p. 28).

The third argument - the psychological support argument - deals with types of thought, of feeling and of self-comprehension that give substance to democratic citizenship. Pateman (1970) and Dahl (1985) are authors that present this argument, which defends the extension of self-government to non-democratic spheres of labor. This point of view claims that "[s]ince capitalist property relations vest final authority in the owners of capital, they limit the extent of intra-firm democracy, thereby fostering passivity and a narrower basis of political judgment. For this reason they are not well-suited to a democratic society" (Cohen, 1989, p. 29).

The fourth argument - the resource constraint argument - deals with the negative influence of the unequal distribution of wealth and income in the democratic process. This inequality creates obstacles for both the equal access to the political arena and the equality of having power to influence results in the democratic process. This aspect is discussed by Downs (1957). As a result, "[a] well-functioning democracy, based on the principle that political opportunity should not be a function of economic position, would therefore be aided by a more equal distribution of material resources than is characteristic of capitalism" (Cohen, 1989, p. 29).

In order to deal with these four different sources of tension between capitalism and democracy, Cohen (1989) discusses the role of deliberative democracy, relying upon several authors including Habermas (1981). In this argument, there is a suggestion on the need for thinking about diverse institutional forms of democracy that should necessarily go beyond representative democracy. After the discussion on deliberative democracy, Cohen (1989, pp. 39-49) deals with the relationship between democracy and socialism, pinpointing the workings of democratic institutions in order to answer two questions: 1) the public control of investments; 2) workers' self-management. In the academic debate, Cohen's position is important because he presents arguments for self-administration even in big businesses (p. 48). Nove (1983), in the third round of debate on plan and markets, was quite skeptical about this possibility of democratization. The interpretation of Cohen's position (1989) outlined here emphasizes a theoretical stance that recognizes the growing complexity of the economic and State spheres; but, contrary to Habermas, does not withdraw them from the reach of democratization. 
Ellen Wood (1995) presents another central element for the discussions on democracy: its role in the substitution of the mechanism of the market. Wood suggests that democracy become the "driving mechanism of the economy" (p. 290), a new economic regulator (p. 292) (see also Cohen, 2009).

This approach to the democratic process, associated with a strong capacity for institutional innovation, is necessary for responding to the diverse demands set by new institutional arrangements. Innovation systems, welfare systems, financial institutions and the international order demand that democratic institutions have a greater ability of dealing with increasingly complex matters. In another manner, this articulation reinforces the precedence of democracy. Furthermore, its association to an essential requirement, the reduction of the working day, repositions the role of the scientific application of technology - here there is an important interaction with innovation systems.

Another important result of the process of the metamorphosis of the capitalist system, the quantitative and qualitative increase of the State's action, always puts forward the question of its democratic control. For this reason, the development and improvement of democratic institutions become significant for defining the priorities of spending and the use of public resources. This quantitative and qualitative increase in state intervention should have, as a counterpart, similar evolution in terms of the reach of democratic institutions.

Lastly, it is also worth noting that the precedence of democracy determines the role of the programmatic discussion, given its very role in gaining the support and sympathy for experimentation.

\section{4- CONCLUDING REMARKS: THE PERMANENT DISPUTE ON VISBILE SEEDS}

As visible seeds of socialism become the institutional materialization of important results from social struggles or of strong emancipatory elements, the uncertainty about their future should be re-emphasized. However, beyond this more general uncertainty, there is still a specific struggle between capital and the potentialities in terms of a socialist perspective. Capital can recognize the emergence of these visible seeds as a potential for the expansion in its realm of action. These struggles, which are often generalized, can actually embody a drive for the structural changes in the capitalist system, transforming them into part of the capitalist dynamic in the long run. These struggles refer to all of the visible seeds.

The identification of "visible seeds" assumes this permanent dispute, which may be incorporated by the capitalist dynamics and can constitute, at the very least, a civilizing element of capitalism.

This approach in relation to the destiny of "visible seeds" offers a new perspective from some debates, particularly the Austrian School, with Hayek's work being identified as a systematic confrontation against the emergence and/or evolution of visible seeds. In Hayek's works it is possible to identify his opposition to these visible seeds. There is a general position in Hayek (1979) against social and democratic experiments that can be detected by the adherence to "spontaneous order" and the complete opposition to any attempt at institutional innovation through democracy and "rational design". For this reason, it is possible to consider Hayek as an intellectual aware of the emergence of visible seeds of socialism and always positioned to confront them. This way of interpreting 
contemporary debates suggests new terms for re-starting the debates on the possibility of socialism proposed by the Austrian School (Lavoie, 1985b).

A programmatic recomposition of the transition to socialism does not limit itself to the incorporation of the "visible seeds" discussed in this article. Greater interactions between the institutional arrangements presented here presume political and social action, which can be recovered by an updated program with a socialist perspective. This increased interaction can represent a leap in the quality of the political struggle and add a new dynamic element to the framework of social structures.

The interrelationship among these four institutional arrangements presupposes the establishment of a proper dynamic, resulting from the reciprocal and positive influences among them. The precedence of democracy and the development of democratic institutions are also important for paving the path for a new dynamic that enables the transformation of innovations systems, of welfare systems and of the financial system.

What is worth highlighting here is the potential for a new dynamic to emerge, which articulates these institutional arrangements. This new dynamic, nevertheless, as with all social and economic processes, will not have its results previously known, since there are innumerous possibilities of development and of non-intentional results. It is not essential now to pinpoint the final elements of this process of transition to socialism. It is worth delimiting the initial elements and the sources of the process: the subordination to democratic processes. The result of this democratic dynamic contributes to overcoming the Realm of Capital. Throughout this process, the future and role of various institutions will be defined, including that of money and the market.

The international dimension of this process should be considered here. The global dynamics of capitalism requires the emergence of international elements that are basic components to any proposal for the transition to socialism. All "visible seeds" have a strong international component. 


\section{REFERENCES}

ABENDROTH, W. (1965) A história social do movimento trabalhista europeu. Rio de Janeiro: Paz \& Terra (1977).

AMSDEN, A. H.. Asia's next giant: South Korea and late industrialization. New York/Oxford: Oxford University, 1989.

ARRIGHI, G. (1994). O longo século XX: dinheiro, poder e as origens do nosso tempo.Rio de Janeiro/São Paulo: Contraponto/Unesp (1996).

BANK FOR INTERNATIONAL SETTLEMENTS (2009). $79^{\text {th }}$ Annual Report. Basel: BIS. Available at : www.bis.org. Acess in 20/02/2010.

BARR, N.. The economics of the welfare state. Stanford: Stanford University Press $\left(3^{\text {rd }}\right.$ edition), 1998.

BECKER, E.; McVEIGH, P. Social funds in the United States: their history, financial performance and social impacts. In: FUNG, A.; HEBB, T.; ROGERS, J.. Working capital: the power of labor's pensions. Ithaca: Cornell University Press, pp. 44-66, 2001.

BERNSTEIN, E. (1899). Socialismo evolucionário. Rio de Janeiro: Jorge Zahar Editora/Instituto Teotônio Vilela (1997)

BLACKBURN, R.. Fin de siècle: socialism after the crash. New Left Review, n. 185, pp. 566, 1991.

BLACKBURN, R.. Banking on death: or, investing in life - the history and future of pensions. London: Verso, 2002.

BURCZAK, T.. Socialism after Hayek. Ann Arbor: The University of Michigan Press, 2006.

CARVALHO, F. C.. Keynes and the reform of capitalist social order. Journal of Post Keynesian Economics, v. 31, n. 2, pp. 191-212, 2008.

CHESNAIS, F.. Le capital de placement: accumulation, internationalisation, effects économiques et politiques. In: CHESNAIS, F. (org.) La finance mondialisée: racines sociales et politiques, configuration, conséquences. Paris: Éditions La Découverte, pp. 15-50, 2004.

COHEN, G. A.. Why not socialism? Princeton: Princeton University Press, 2009.

COHEN, J.. The economic basis of deliberative democracy. Social Philosophy \& Policy, v. 6, n. 2, pp. 25-50, 1989.

COHEN, J.; ROGERS, J.. Associations and democracy. London: Verso, 1995.

DRUCKER, P. (1976). A revolução invisível: como o socialismo-fundo-de-pensão invadiu os Estados Unidos. São Paulo: Livraria Pioneira Editora (1977).

ELSON, D. Market socialism or socialization of the market. New Left Review, n. 172, Nov.-Dec., 1988, pp. 3-44. 
ENGELEN, E. Resocializing capital: putting pension savings in the service of "financial pluralism". Politics \& Society, v. 34, n. 2, pp. 187-218, 2006

ESPING-ANDERSEN, G.. Politics against markets: the social democratic road to power. Cambridge: Cambridge University Press, 1985

ESPING-ANDERSEN, G.. The three worlds of welfare capitalism. Cambridge: Polity, 1990.

ESPING-ANDERSEN, G.. Welfare states and the economy. In: SMELSER, N.; SWEDBERG, R. (eds) The handbook of economic sociology. Princeton: Princeton University Press, pp. 711-732, 1995.

FREEMAN, C.. The greening of technology and models of innovation. Technological Forecast and Social Change, v. 53, pp. 27-39, 1996.

FREEMAN, C.; LOUÇÃ, F.. As time goes by: from the industrial revolutions and to the information revolution. Oxford: Oxford University, 2001.

FUNG, A.; HEBB, T.; ROGERS, J.. Working capital: the power of labor's pensions. Ithaca: Cornell University Press, 2001.

GOODIN, R.. Reasons for welfare: the political theory of the welfare state. Princeton: Princeton University Press, 1988.

HABERMAS, J. (1981). La teoria de la acción comunicativa. Madri: Taurus, 1987.

HAYEK, F. A. (1935). Socialist calculation I: the nature and history of the problem. In: Individualism and economic order. Chicago: The University of Chicago Press, pp. 119-147 (1948).

HAYEK, F. A. (1979). The political order of a free people. In: Law, legislation and liberty. Volume 3. London: Routledge, 1982.

HEBB, T.. Introduction: the challenge of labor's capital strategy. In: FUNG, A.; HEBB, T.; ROGERS, J. Working capital: the power of labor's pensions. Ithaca: Cornell University Press, pp. 1-12, 2001.

HODGSON, G.. Economics and utopia: why the learning economy is not the end of history. London: Routledge, 1999.

LASSEY, M. L.; LASSEY, W. L.; JINKS, M. J. (Health care systems around the world: characteristics, issues, reforms. New Jersey: Prentice Hall, 1997.

LAVOIE, D.. Rivalry and central planning: the socialist calculation debate reconsidered. Cambridge: Cambridge University Press, 1985 b.

LEMOS, M. B.. Usiminas: avaliação do processo de privatização e diretrizes para a ação. Relatório Final de Pesquisa. Belo Horizonte: Cedeplar-UFMG, 1991.

LIJPHARDT, A . Patterns of democracy. New Haven/London: Yale University Press, 1999.

MANDEL, E. . In defense of socialist planning. New Left Review, n. 159, Sep.-Oct., pp. 4$37,1986$.

MARX, K. (1857-58) Grundrisse. London: Penguin Books, 1973. 
MARX, K.. (1859) Para a crítica da economia política. In: MARX. São Paulo: Abril Cultural (1982), pp. 3-113, 1982.

MARX, K (1867). Capital, Volume I. London: Penguin Books, 1976.

MARX, K. (1875) Crítica do Programa de Gotha. In: MARX, K.; ENGELS, F. Textos volume 1. São Paulo: Ediçoes Sociais pp. 221-243,1977.

MARX, K (1885). Capital, Volume II. London: Penguin Books, 1978.

MARX, K (1894). Capital, Volume III. London: Penguin Books, 1981.

MINSKY, H. (1982). Can “it” happen again? Essays on instability and finance. New York: M. E. Sharp, 1984.

MISHKIN, F.; EAKINS, S.. Financial markets and institutions. Boston: Pearson/Prentice Hall, $6^{\text {a }}$ edição, 2009.

MOUFFE, C.. Democratic politics today. In: MOUFFE, C. (ed) Dimensions of radical democracy. London: Verso, pp. 1-14, 1992

NELSON, R. (ed.) National innovation systems: a comparative analysis. New York, Oxford: Oxford University, 1993.

NOVE, A.. The economics of feasible socialism. London: George Allen \& Unwin, 1983.

NOVE, A.; NUTI, M. (eds). Socialist economics. London: Penguin, 1972.

PATEMAN, C. (1970) Participação e teoria democrática. São Paulo: Paz e Terra, 1992.

POLANYI, K. (1944) A grande transformação: as origens de nossa época. Rio de Janeiro: Editora Campus, 1980.

POLLIN, R.. Financial structures and egalitarian economic policy. New Left Review, n. 214, November-December, pp. 26-61,1995.

PREOBRAJENSKY, E. (1926). Nova economica. Rio de Janeiro: Paz \& Terra, 1979.

PRYCHITKO, D. L. . Markets, planning and democracy. Cheltenham: Edward Elgar, 2002.

PRZEWORSKY, A. (1990). Estado e economia no capitalismo. Rio de Janeiro: RelumeDunará , 1995.

ROEMER, J.. Equal shares. London/New York: Verso, 1996.

ROSDOLSKY, R. (1968) Genesis y estructura de "El Capital” de Marx. México: Siglo XXI, 1978.

SILVER, B. (2003) Forces of labor: workers' movements and globalization since 1870. Cambridge: Cambridge University Press.

SIMMEL, G. (1907) The philosophy of money. London: Routledge. 3rd edition (2004)

SKIDELSKY, R. . John Maynard Keynes: the economist as a savior, 1920-1937. New York: Penguin Books, 1992 
STACHURA, P. D.. Social policy and social welfare in Germany from the mid-nineteenth century to the present. In: OGILVIE, S.; OVERY, R. Germany: a new social and economic history. Volume III - since 1800. London: Arnold, pp. 227-250, 2003.

STIGLITZ, J. E. . Wither socialism? Cambridge, Mass: MIT, 1994.

TROTSKY, L. (1937) A revolução traída. São Paulo: Global Editora, 1980.

WADE, R. . Governing the market: economy theory and the role of government in East Asian industrialization. Princeton: Princeton University, 1990.

WEBER, M. (1918) Conferência sobre o socialismo. In: FRIDMAN, L. C. (org.) $O$ socialismo. Rio de Janeiro: Relume-Dumará,1993.

WEBER, MARIANE (1926) Max Weber: uma biografia. Niterói: Casa Jorge Editorial, 2003.

WOOD, E. M. (1995) Democracy against capitalism: renewing historical materialism. Cambridge: Cambridge University Press, 1995.

WOOD, E. M.. Empire of capital. London/New York: Verso, 2003.

WRIGHT, E. O.. Compass points: towards a socialist alternative. New Left Review, v. 41, Sept/Oct, pp. 93-124, 2006.

ZYSMAN, J. Governments, markets, and growth: financial systems and the politics of industrial change. Ithaca: Cornell University, 1983. 